\title{
Efek mediasi totalisme Islam pada hubungan antara Social Dominance Orientation dan Right-Wing Authoritarianism terhadap sikap politik konservatisme Islam
}

\author{
Istiqomah1,2, Muhammad Abdan Shadiqi ${ }^{3 *}$, Bagus Takwin'1, \& Hamdi Muluk ${ }^{1}$ \\ ${ }^{1}$ Fakultas Psikologi, Universitas Indonesia, Depok, Jawa Barat \\ ${ }^{2}$ Fakultas Psikologi, Univesitas Mercu Buana, Jakarta Barat, DKI Jakarta \\ ${ }^{3}$ Program Studi Psikologi, Fakultas Kedokteran, Universitas Lambung Mangkurat, Banjarbaru, \\ Kalimantan Selatan
}

\begin{abstract}
Abstrak
Studi ini berusaha menunjukkan peran dari totalisme Islam sebagai mediator dari hubungan antara Social Dominance Orientation (SDO) dan Right-Wing Authoritarianism (RWA) terhadap sikap politik konservatif Muslim. Studi ini menggunakan pendekatan cross-sectional melalui survei non-eksperimental terhadap 528 mahasiswa Muslim di Jabodetabek (Mean Usia= 21,4 tahun, SD = 3,36). Kami menggunakan 4 alat ukur self-reported dengan skala likert 1-7. Teknik analisis yang digunakan adalah melalui regresi model mediasi PROCESS Macro. Hasil penelitian menunjukkan bahwa SDO dan RWA tidak dapat memprediksi sikap politik konservatif Muslim secara langsung (direct effect). Kami menemukan totalisme Islam secara signifikan memediasi secara penuh (fully mediation) hubungan antara SDO dan RWA terhadap sikap politik. Hasil ini menggambarkan bahwa pada mahasiswa Muslim Indonesia, sikap politik mereka cenderung dipengaruhi oleh faktor terkait agama. Dengan kata lain, agama tidak dapat dipisahkan dari ideologi politik konservatif Muslim Indonesia.
\end{abstract}

Kata kunci: Totalisme Islam, Social Dominance Orientation, Right Wing Authoritarianism, Sikap Politik, Konservatisme Islam.

\begin{abstract}
This study attempts to show the totalism role of Islam as a mediator in the relationship between Social Dominance Orientation (SDO) and Right-Wing Authoritarianism (RWA) towards the political conservatism of Muslims. This study uses a cross-sectional approach through a non-experimental survey of 258 Muslim university students in the Jabodetabek region (Mean age $=21.4$ years old, $\mathrm{SD}=3.36$ ). Moreover, this study employs 4 self-report measurements with a Likert scale of 1-7. The analytical technique used in this study is the PROCESS Macro mediated regression model. This study shows that SDO and RWA fail to predict the political conservatism of Muslims as a direct effect. It is also founded that the totalism of Islam significantly mediates the relationship of SDO and RWA towards political attitude (full mediation). This result demonstrates that for Muslim university students, political attitudes tend to be influenced by religious factors. In other words, religion could not be separated from the conservative political ideology of Muslims in Indonesia.
\end{abstract}

Keywords: Islam Totalism, Social Dominance Orientation, Right Wing Authoritarianism, Political Attitude, Islamic Conservatism.

\section{Pendahuluan}

Pada tahun 2002 muncul usulan memasukkan rujukan syariah (Piagam Jakarta) ke dalam konstitusi meskipun pada akhirnya ditolak, tetapi aspirasi ini berubah menjadi hak otonomi daerah melalui peraturan bernuansa syariah seperti aturan berpakaian wanita, anjuran mengaji, hingga sholat berjamaah (Bruinessen, 2013). Fenomena ini didukung oleh survei yang dilakukan pada tahun 2002 dan 2010, survei menunjukkan adanya peningkatan Islamisme di kalangan umat Muslim Indonesia (Sakai \& Fauzia, 2014). Salah satu fenomena besar lain terjadi tahun 2019 dengan munculnya gerakan penolakan Basuki Tjahaja Purnama (Ahok) menjadi gubernur DKI Jakarta karena bukan seorang muslim. Fenomena ini menjadi pertanyaan apakah terdapat peningkatan konservatisme di antara Muslim Indonesia (Lindsey, 2016) atau sebagai indikasi per-
Naskah masuk: 11 Juli 2020

Naskah diterima: 3 Desember2020
*Program Studi Psikologi, Fakultas Kedokteran, Univesitas Lambung Mangkurat Jl. A. Yani, Km. 36, Banjarbaru, Kalimantan Selatan, Indonesia 70714. E-mail: abdan.shadiqi@ulm.ac.id 
ubahan besar dalam agama, sosial dan politik atau hanya dinamika politik sehingga tidak mungkin untuk menjadi pola yang berpengaruh di tahun-tahun mendatang? (Mietzner \& Muhtadi, 2018).

Indonesia adalah negara dengan jumlah mayoritas muslim sebanyak 207.176.162 jiwa (87\%) berdasarkan data Badan Pusat Statistik tahun 2010. Komunitas muslim di Indonesia tergolong sebagai "indigenised" sehingga memberikan varian penting dalam pelaksanaan agamanya (Fealy \& White, 2008). Dalam pelaksanaan ajaran Islam banyak terdapat perbedaan untuk memahami dan menjalankan ajaran tersebut, termasuk juga perbedaan dalam penerapan agama pada isu politik. Seperti yang diketahui, Islam mempunyai sifat multi-interpretatif, tidak pernah ada pandangan yang tunggal mengenai bagaimana seharusnya Islam dan politik dikaitkan secara pas, sehingga Muslim di Indonesia beragam (Effendy, 1998).

Muncul dua kutub pemikiran yang berbeda. Kubu pertama adalah Muslim yang melihat Islam sebagai ekspresi humanisme internasional yang sepenuhnya kompatibel dengan gagasan sekuler demokrasi pluralistis, berfokus pada masyarakat sipil, hak asasi manusia, toleransi, dan isu-isu gender, mereka telah berjuang untuk memajukan reformasi demokrasi yang diprakarsai pada tahun 1998. Di ujung lain, kubu kedua yaitu Muslim konservatif yang telah menyatakan keberatan dengan demokratisasi Indonesia dan kebencian terhadap diplomatiknya hubungan dengan negara-negara Barat. Kelompok-kelompok ini telah menekankan pada dukungan hukum Islam, kekhalifahan, atau negara pan-Islam (Kraince, 2000). Kedua kutub ini adalah gambaran fenomena sikap politik Muslim di Indonesia yang menjadi fokus kajian di penelitian ini.

Beberapa penelitian dalam psikologi sosial telah mengungkap faktor disposisi yang mempengaruhi sikap politik. Sikap politik (seperti konservatisme) sebenarnya ditentukan, sebagian besar oleh perbedaan orientasi kepribadian seperti otoritarianisme sayap kanan atau RWA (Altemeyer \& Hunsberger, 1992; Duckitt, Bizumic, Krauss, \& Heled, 2010; Harnish, Bridges, \& Gump, 2018) dan orientasi dominasi sosial atau SDO (Pratto, Sidanius, Stallworth, \& Malle, 1994; Mifune \& Yokota, 2018). Namun, hasil temuan lain pada dua dari 14 sampel penelitian di Selandia Baru menunjukkan bahwa RWA tidak sepenuhnya signifikan memprediksi sikap politik konservatisme (Wilson \& Sibley, 2012). Kemudian, SDO juga tidak ditemukan signifikan memprediksi konservatisme sosial dan konservatisme kebijakan luar negeri (Harnish dkk., 2018). Uraian temuan-temuan ini cukup mene-gaskan bahwa RWA dan SDO tidak konsisten menjelaskan sikap politik konservatisme, sehingga menjadi isu empiris yang menarik untuk dikaji kembali. Terutama, ketika kajian ini diteliti pada masyarakat Indonesia yang mayoritas beragama Islam dan memiliki dualisme kutub pandangan ideologis mengenai kaitan agama dengan politik.

Pada masyarakat Muslim, orientasi ideologi yang menggambarkan sikap politik dapat dipetakan menggunakan konsep totalisme Islam yaitu konsep religiusitas yang menjelaskan kecenderungan untuk memandang Islam tidak hanya sebagai "agama" dalam arti sempit dari kepercayaan teologis, doa pribadi dan ibadah ritual, tetapi juga sebagai cara hidup secara menyeluruh dengan panduan untuk perilaku politik, ekonomi, dan sosial (Shepard, 1987). Meskipun totalisme Islam dan religiusitas berbeda secara konseptual tetapi kedua istilah ini masih saling berkaitan, yakni keduanya bersumber dari kepercayaan teologis.

Pada konsep religiusitas, individu yang sangat religius cenderung memiliki posisi politik yang lebih konservatif daripada individu yang kurang religius (Malka, Lelkes, Srivastava, Cohen, \& Miller, 2012; Stangor, 2011; Kelly \& Morgan, 2008; Layman \& Green, 2005). Selain itu survei nasional di Amerika Serikat tahun 1996 hingga 2008 menemukan hubungan religiusitas berkaitan dengan sikap dan nilai konservatif pada individu yang terlibat dalam politik (Malka, dkk. 2012). Konsep lain yang juga cukup dekat tetapi berbeda secara konseptual dengan totalisme Islam adalah fundamentalisme beragama (Religious Fundamentalism atau RF) (Lifton, 1989). Muslim yang lebih religius akan lebih tinggi RFnya (Hannover, Gubernath, Schultze, \& Zander, 2018). Harnish dkk. (2018) menemukan RF berkorelasi dengan konservatisme sosial dan konservatisme ekonomi. Riset lain menemukan bahwa jika dibandingkan dengan RWA, RF ditemukan lebih kuat memediasi hubungan antara agama dan sikap terhadap Lesbian dan Gay (Johnson, dkk., 2011).

Penulis akan berusaha menjelaskan sebuah kebaruan temuan ilmiah atas inkonsistensi temuan tentang hubungan RWA dan SDO dengan sikap politik melalui peran agama yang dalam hal ini menggunakan konsep totalisme Islam. Hal ini dikarenakan sebanyak 95\% orang Indonesia dilaporkan oleh Pew Research Center menyatakan bahwa agama sangat penting dalam kehidupan mereka (Theodorou, 2015). Sebagai sebuah budaya, agama sudah tertanam kuat di benak orang Indonesia (Muluk, Hudiyana, \& Shadiqi, 2018). Oleh karena itu, orang Indonesia terbiasa menilai banyak aspek kehidupan mereka dari perspektif agama (Mujani, 2007), termasuk sikap mereka terhadap bagaimana masyarakat seharusnya berfungsi baik secara sosial 
maupun ekonomi. Pertanyaan penelitian yang diajukan pada studi ini adalah apakah SDO, RWA, dan totalisme Islam mampu memprediksi sikap politik Muslim? Bagaimana pola interaksi SDO, RWA, dan totalisme Islam dalam memprediksi sikap politik Muslim? Secara khusus kami berargumentasi bahwa totalisme Islam dapat menjadi faktor mediator dari hubungan SDO dan RWA terhadap sikap politik Muslim. Pada bagian selanjutnya kami akan menjelaskan arah berpikir untuk menjelaskan hipotesis penelitian di studi ini.

\section{Sikap politik muslim dan totalisme Islam}

Hubungan negara dan agama merupakan persoalan yang banyak menimbulkan perbedaan yang terus berkelanjutan tidak ada henti-hentinya di panggung dunia intelektual disebabkan oleh perbedaan pandangan dalam menerjemahkan agama sebagai bagian dari negara, dan negara merupakan bagian dari dogma agama (Azra, 2003). Dalam tradisi intelektual Islam, ada tiga persoalan yang selalu dibicarakan terkait kepemimpinan politik dalam negara. Pertama, soal pemimpin yang kurang layak (imāmatul mafụūl). Kedua, soal pemimpin yang suka maksiat (imāmatul fāsiq). Dan ketiga, soal pemimpin non-Muslim (imāmatul kāfir). Mereka yang menentang "keharaman kepemimpinan non-muslim" dinilai tidak memahami secara mendalam ayat ayat al-Qur'an maupun al-hadits baik dari sisi maksud dan tafsirnya, tidak melacak sebab-sebab turunnya ayat-ayat kepemimpinan dan cenderung mempermainkan makna harfiahnya dan menunjukkan kekeliruan yang fatal. Sementara mereka yang mengharamkan kepemimpinan non-muslim menyebutkan mereka yang menjadikan orang kafir sebagai pemimpin bagi umat Islam berarti menentang Allah SWT dan Rasulullah SAW serta Ijma' Ulama (Izomiddin, 2017).

Beberapa muslim meyakini syariat Islam harus dijalankan secara menyeluruh (totalisme), karena Islam adalah ajaran yang sempurna sehingga dalam pemahaman dan pengamalannya harus menyeluruh atau kaffah (udkhulu fil islam kaffah). Islam sebagai wahyu Allah yang dibawa oleh para Nabi sejak Nabi Adam hingga Nabi Muhammad merupakan agama atau ajaran yang lengkap dan sempurna, yang mengatur seluruh kehidupan umat manusia. Tidak ada satu aspek kehidupan pun yang lepas dari pengaturan Islam. Akibatnya sebagian Muslim menginginkan agama Islam menjadi pertimbangan utama dalam pembuatan kebijakan sosial, ekonomi dan politik (Nashir, 2013).

Totalisme dalam Islam berhubungan dengan bagaimana Muslim memahami Syariah sebagai panduan moral. Sebagai panduan, ajaran Islam diyakini beberapa muslim memberikan panduan secara menyeluruh dalam semua aspek kehidupan termasuk politik. Konsep totalisme Islam ini dipaparkan pertama kali oleh Shepred (1987) dan belum ditemukan hasil riset terkini yang mengaitkan totalisme Islam dengan RWA, SDO, dan sikap politik. Untuk itu, kami berusaha menjelaskan totalisme Islam dengan menggunakan konsep yang terdekat, seperti fundamentalisme beragama, sebagai dasar asumsi teoretis.

Lifton (1989) mengidentifikasi totalisme sebagai sinonim dari 'fundamentalisme agama dan politik' karena fundamentalisme merupakan kecenderungan untuk mendefinisikan dunia secara absolut. Meskipun kami menggunakan konsep fundamentalisme agama pada penjelasan di bagian ini, tetapi perlu ditegaskan bahwa totalisme Islam dan fundamentalisme agama sendiri terdapat perbedaan. Jika fundamentalisme agama menitik-beratkan pada komitmen mendalam pada ajaran agama, totalisme Islam memandang agama perlu diimplementasikan secara menyeluruh pada semua aspek kehidupan tidak terbatas pada ritual agama saja. Fundamentalisme sebagai the quest for absolute atau totalistic belief system, yaitu keyakinan agama yang ditandai oleh literal teks-teks suci yang mengandung kebenaran absolut (Lifton, 1989).

Ada sifat kognitif serupa terkait pemrosesan kognitif antara fundamentalisme dengan konservatif. Politik konservatif mungkin lebih cenderung untuk menghindari rangsangan yang ambigu dan lebih memilih kepastian, demikian juga para fundamentalis agama ingin menghindari isu-isu yang memiliki lebih satu perspektif dan cenderung tunduk pada fatwa agama (Antonenko Young, Willer, \& Keltner, 2013). Hal ini bisa disebabkan karena fundamentalis dan konservatif merupakan individu dengan kebutuhan tinggi pada ketertutupan kognitif (need cognitive closure) yang meyakini sebuah pendapat atau pandangan dengan kuat dan stabil serta dengan cepat dan menolak ketika pandangan mereka dikonfrontasi (Webster \& Kruglanski, 1994). Individu dengan ketertutupan kognitif yang tinggi saat berinteraksi dengan kelompok dan ia belum mempunyai pendapat atau pandangan, ia akan lebih suka melakukan "seizing" atau mengambil opini rekan kelompok sehingga mudah dipersuasi (De Grada, Kruglanski, Mannetti, \& Pierro, 1999). Sebaliknya, individu yang sudah memiliki pendapat atau pandangan maka ia cenderung melakukan "freezing" atau mempertahankan opininya, sehingga lebih sulit dipersuasi (De Grada dkk., 1999). Berdasarkan penjelasan ini, kami berhipotesis bahwa ada peranan totalisme Islam terhadap sikap politik konservatisme (Hipotesis 1). 


\section{Right-Wing Authoritarianism dan Social Dominance Orientation}

Merujuk pada disiplin ilmu psikologi sosial, banyak penelitian terkait dengan motivasi dan kecenderungan psikologis yang mendasari perilaku sosial-politik. Diawali dengan dugaan bahwa faktor kepribadian mendasari ideologi, yaitu ditemukan adanya hubungan antara right-wing authoritarianism dengan dukungan ideologi konservatif (Altemeyer, 1981; Altemeyer, 1998; Dupree \& Fiske, 2019; Harnish dkk., 2018). Harnish dkk. (2018); Haslam dan Levy (2006); Wilson dan Sibley (2012) menggunakan proses motivasi dari variabel right-wing authoritarianism (RWA) dan social dominance orientation (SDO) untuk memahami ideologi politik. Sikap ideologi dipengaruhi oleh faktor kepribadian dimana hubungan keduanya dimediasi melalui pandangan dunia sosial sebagai ancaman atau daya saing atas dominasi, kekuasaan, dan sumber daya kelompok. Melalui model $a$ dual-process motivational digambarkan bahwa RWA dan SDO mengekspresikan perbedaan motivasi, keyakinan pandangan dunia sosial, dimensi sifat kepribadian, dan pengaruh lingkungan sosial, yang dapat mempengaruhi perilaku sosial-politik dengan cara yang berbeda dan melalui mekanisme yang berbeda. RWA dicirikan sebagai dorongan akan keamanan dan kontrol berdasarkan pada keyakinan bahwa dunia merupakan sebuah ancaman dan bahaya, sementara SDO sebagai dorongan untuk kekuasaan dan dominasi berdasarkan keyakinan pada dunia yang keras dan kompetitif (Duckitt \& Sibley, 2009). Hipotesis yang dibangun dari penjelasan ini adalah ada peranan RWA terhadap sikap politik konservatisme (Hipotesis 2) dan ada peranan SDO terhadap sikap politik konservatisme (Hipotesis 3).

\section{Totalisme Islam sebagai Mediator}

Riset lain menjelaskan inkonsistensi RWA (Wilson \& Sibley, 2012) dan SDO (Harnish, dkk., 2018) dalam menjelaskan konservatisme, sehingga ini membawa langkah untuk mengembangkan riset yang melibatkan faktor lain. Untuk menjelaskan hubungan RWA dengan totalisme, kami mulai dengan menggunakan memaparkan hubungan RWA dengan religiusitas. Hal ini sesuai dengan penjelasan kami di awal bagian pendahuluan bahwa totalisme Islam dan religiusitas saling berkaitan, meskipun kedua konsep ini berbeda. Jika dihubungkan dengan agama, RWA mempunyai korelasi tinggi dengan religiusitas (Katolik) karena agama sebagai ajaran yang berasal dari Tuhan bersifat suci mengandung nilai-nilai konvensional yang harus dipertahankan kepatuhan yang kuat pada nilai dan norma konvensional adalah salah satu dimensi dari sikap otoritarian (Altemeyer, 1988; Altemeyer \& Hunsberger, 1992; Sinn \& Hayes, 2018). Di sisi lain, hubungan antara SDO dan religiusitas cenderung tidak signifikan (Altemeyer, 2004; Altemeyer \& Hunsberger, 1997; Heaven \& Connors, 2001) atau bahkan negatif, masuk akal karena agama dapat dianggap sebagai hierarki yang melemahkan mitos legitimasi (Dru, 2007; Roccato, 2008).

Beberapa ilmuwan sosial berpendapat bahwa terdapat hubungan alami antara religiusitas dan politik konservatif. Menurut pandangan ini, nilai dan preferensi yang terkait dengan religiusitas secara alamiah terkait dengan konservatif. Jost dan rekannya menawarkan kerangka kerja untuk memahami hubungan psikologis antara konservatisme politik dan berbagai karakteristik nonpolitik, termasuk yang terkait dengan religiusitas (misalnya, Jost, Glaser, Kruglanski, \& Sulloway, 2003). Mereka berpendapat bahwa motif yang mendasari konservatisme juga mendasari karakteristik lain, termasuk kecenderungan religius, dan bahwa ini membantu menjelaskan kontinuitas historis yang tampak dalam hubungan antara religiusitas dan politik konservatif (Jost, 2007; Jost, Nosek, \& Gosling, 2008). Totalisme Islam, sebuah bentuk religiusitas tentang keyakinan terhadap ajaran Islam sebagai pedoman menyeluruh dalam kehidupan sosial dan politik diduga berhubungan dengan politik konservatif.

Agama dan politik berakar pada kebutuhan psikologis yang sama (Friesen, Campbell, \& Kay, 2015). Seperti diketahui bahwa korelasi antara RWA dan preferensi politik dapat ditemukan jika agama bercampur kuat dengan politik, misalnya di Israel (Altemeyer, 1996). Lifton (1989) menerangkan bahwa totalisme lebih dekat dengan istilah fundamentalisme beragama (religious fundamentalism atau RF), meskipun kedua istilah ini tetap terdapat perbedaan seperti yang telah kami jelaskan pada bagian tinjauan teori (lihat pembahasan sebelumnya: Sikap Politik Muslim dan Totalisme Islam). Untuk diketahui totalisme Islam masih belum diteliti. Sementara itu, RWA dan SDO terbukti berkorelasi dengan RF (Hathcoat \& Barnes, 2010; Harnish dkk., 2018; Lazar \& Hammer, 2018).

Beberapa riset memang menemukan bahwa RWA menjadi mediator hubungan antara religiusitas (Tsang \& Rowatt, 2007) dan RF (Johnson dkk., 2012) dengan prasangka. Namun riset Johnson dkk. (2011) yang menemukan RF lebih kuat menjadi mediator dari hubungan antara religiusitas dengan sikap terhadap lesbian dan gay, dibandingkan RWA. Riset lain juga menemukan bahwa RF signifikan memediasi 
hubungan antara RWA dengan etnosentrisme beragama, efek mediasi RF ini lebih kuat dibandingkan efek mediasi identifikasi pada kelompok agama (Banyasz, Tokar, \& Kaut, 2016).

Berdasarkan karakteristik RWA dan sikap politik konservatif, diduga model hubungan langsung antara RWA dengan sikap politik konservatif dan model hubungan yang dimediasi oleh totalisme Islam. Hubungan mediasi tampaknya masuk akal bahwa totalisme Islam berfungsi sebagai mekanisme dimana RWA terwujud dalam pengertian religius dengan karakteristik dogmatis dan kepatuhan terhadap nilainilai konvensional (agama). Meskipun tidak secara eksplisit meneliti totalisme Islam dan konservatisme, dari beberapa hasil empiris ini kami berhipotesis bahwa totalisme Islam dapat memediasi hubungan antara RWA dengan sikap politik (Hipotesis 4) dan totalisme Islam dapat pula memediasi hubungan antara SDO dengan sikap politik (Hipotesis 5).

\section{Metode Penelitian}

\section{Partisipan, Desain, dan Prosedur}

Studi ini menggunakan metode survei dengan pengambilan data menggunakan accidental sampling di DKI Jakarta. Data yang dikumpulkan sebanyak 528 partisipan. Rata-rata usia responden adalah 21,4 tahun (SD $=3,36)$. Partisipan memberikan respon (self-reported) terhadap kuesioner penelitian (Stangor, 2011). Studi ini adalah penelitian kuantitatif dengan desain cross-sectional non-eksperimental. Alat ukur diberikan secara langsung (paper-andpencil). Alat ukur dimulai dengan lembar persetujuan, isian faktor demografi dan pengisian kuesioner dari variabel-variabel utama.

\section{Instrumen Penelitian}

Sikap politik. Alat ukur sikap politik secara orisinal terdiri dari 3 dimensi, yakni dimensi religiusitas, ekonomi, dan sosial. Pada riset ini kami hanya menggunakan dimensi religiusitas. Variabel ini didefinisikan secara operasional sebagai sikap individu tentang bagaimana seharusnya negara Indonesia diatur pada dimensi keagamaan. Kami menggunakan alat ukur ideologi politik Indonesia yang dikembangkan oleh Muluk dkk. (2018) yang telah divalidasi pada 5.077 sampel dengan reliabilitas 0,939. Pada riset ini kami hanya menggunakan 4 item pernyataan dari total 12 item alat ukur orisinal melalui 7-poin skala likert $(1$ = Sangat Tidak Setuju, 7 = Sangat Setuju). Pengukuran menggunakan isu-isu yang menjadi perhatian masyarakat saat ini, adapun 4 item pernyataan adalah "Dalam memilih pemimpin negara harus seiman dan seagama". Koefisien reliabilitas $(\alpha)$ alat ukur ini sebesar adalah 0,794 .

Totalisme Islam. Variabel ini didefinisikan secara operasional sebagai skor individu mendukung Islam sebagai cara hidup yang menyeluruh di segala area kehidupan bermasyarakat. Alat ukur ini merupakan adaptasi dari skala religious intensity yang disusun oleh Hassan (2015) memiliki 14 item yang direspon melalui 7-poin skala likert (1 = Sangat Tidak Setuju, 7 = Sangat Setuju). Contoh item totalisme Islam adalah "Masyarakat Muslim harus berdasarkan pada Qur'an dan hukum Syariah". Koefisien reliabilitas $(\alpha)$ alat ukur ini sebesar 0,900 .

Social Dominance Orientation (SD0). Variabel ini didefinisikan secara operasional sebagai derajat tendensi individu mendukung hierarki, ketidaksetaraan, atau dominasi kelompok. Kami menggunakan skala SDO yang dikembangkan oleh Ho dkk. (2012). Alat ukur terdiri dari 5 item pernyataan melalui 7-poin skala likert ( 1 = Sangat Tidak Setuju, 7 = Sangat Setuju). Contoh item alat ukur ini adalah "Sebaiknya beberapa kelompok memiliki status sosial yang tinggi dan kelompok lain berada di bawahnya." Koefisien reliabilitas $(\alpha)$ alat ukur ini sebesar 0,682 .

Right-Wing Authoritarianism (RWA). Variabel ini didefinisikan secara operasional sebagai derajat seberapa individu memiliki tendensi untuk patuh pada otoritas, mengikuti tradisi, dan menghukum devian (penyimpang). Kami menggunakan skala RWA yang dikembangkan oleh Altemeyer (1996) yang divalidasi kembali oleh Passini (2017). Pada penelitian ini, kami menggunakan 6 item pernyataan melalui 7-poin skala likert (1 = Sangat Tidak Setuju, 7 = Sangat Setuju). Contoh item adalah "Negara kita akan hebat jika kita melakukan apa yang dikatakan oleh otoritas." Koefisien reliabilitas $(\alpha)$ alat ukur ini sebesar 0,679.

\section{Hasil Penelitian}

Total responden adalah 528 orang (Laki-laki = 138, Perempuan $=383$, Tidak teridentifikasi $=$ 7). Rata-rata usia responden adalah 21,4 tahun ( $\mathrm{SD}=3,36)$. Sebanyak $47 \%$ responden bersuku Jawa, 22 \% Sunda, 15,7\% Betawi, dan sisanya adalah Batak, Minang, Melayu, Tionghoa dan suku lainnya (campuran). Sebanyak 87,6\% memiliki pendidikan terakhir SMA. Berdasarkan Status Sosial Ekonomi, 86,8\% responden memiliki pengeluaran per bulan kurang dari sama 
dengan Rp4.000.000, sisanya berada di atas Rp4.000.000. Seluruh responden adalah Muslim yang berdomisili di Jadebotabek.

Korelasi antara variabel dilakukan untuk membuktikan adanya hubungan antara variabel sikap politik, totalisme Islam, right-wing authoritarianism (RWA) dan social dominance orientation (SDO) menggunakan mean skor pada tabel 1. Kami menemukan bahwa hanya totalisme Islam $(\mathrm{r}=0,659, \mathrm{p}<0,01)$ dan RWA $(\mathrm{r}=0,189$, $\mathrm{p}<$ 0,01 ) yang berkorelasi dengan sikap politik Muslim. Sementara SDO tidak signifikan berkorelasi dengan sikap politik Muslim ( $\mathrm{r}=0,004$, $\mathrm{p}=$ n.s.). Sementara itu, pada faktor demografi, kami menemukan hanya jenis kelamin $(r=0,127$, $\mathrm{p}<0,01)$ dan pendidikan terakhir $(\mathrm{r}=-0,090, \mathrm{p}<$ 005) yang signifikan berkorelasi dengan sikap politik, meskipun kedua nilai koefisien korelasi terbilang rendah (lihat tabel 1).
Pada tahapan selanjutnya kami melakukan teknik analisis mediasi PROCESS Macro model 4 Hayes (2018) dengan menetapkan RWA dan SDO sebagai variabel independen, totalisme Islam sebagai moderator, dan sikap politik sebagai variabel dependen. Sebelum menganalisis uji hipotesis kami menguji dulu normalitas distribusi data, dan kami menemukan semua variabel tidak terdistribusi normal melalui uji Kormogorov-Smirnov $(\mathrm{p}<0,05)$ dan kami melakukan bootstrapping 1.000 sebagai upaya untuk mengatasi data yang tidak terdistribusi normal (Lockwood \& Mackinnon, 1997; Ng \& Lin, 2016) dan menggunakan skor mean untuk menganalisis 2 model yang berbeda. Adapun hasil analisis mediasi menggunakan uji regresi Hayes model 4 dapat dilihat pada gambar 1-2 (sesuai prediktor yang digunakan) dan tabel 2 .

Tabel 1.

Statistik Deskriptif Korelasi Antar Variabel Prediktor dan Faktor Demografi

\begin{tabular}{|c|c|c|c|c|c|c|c|c|c|c|c|}
\hline & Mean & SD & 1 & 2 & 3 & 4 & 5 & 6 & 7 & 8 & 9 \\
\hline 1. Sikap Politik & 4,265 & 1,456 & 1 & $.659^{* *}$ & $.189 * *$ & .004 & -.034 & $.127^{* *}$ & -.025 & -.054 & $-.090 *$ \\
\hline 2. Totalisme Islam & 4,959 & 1,002 & & 1 & $.348^{* *}$ & $.097^{*}$ & -.023 & -.004 & -.053 & -.045 & -.040 \\
\hline 3. RWA & 4,527 & 0,905 & & & 1 & $.194^{* *}$ & -.095 & .007 & $-.086^{*}$ & -.060 & -.045 \\
\hline 4. SDO & 3,732 & 1,022 & & & & 1 & -.005 & $-.129 * *$ & -.064 & .018 & -.062 \\
\hline 5. Usia & 21,40 & 3,360 & & & & & 1 & $\begin{array}{l}- \\
.134^{*} \\
*\end{array}$ & .019 & $.484^{* *}$ & $.351^{* *}$ \\
\hline 6. Jenis kelamin & - & - & & & & & & 1 & -.010 & -.002 & .051 \\
\hline 7. Etnis & - & - & & & & & & & 1 & .048 & $.103^{*}$ \\
\hline $\begin{array}{l}\text { 8.Pengeluaran } \\
\text { Bulanan }\end{array}$ & - & - & & & & & & & & 1 & $\begin{array}{l}.269 * \\
*\end{array}$ \\
\hline $\begin{array}{l}\text { 9.Pendidikan } \\
\text { terakhir }\end{array}$ & - & - & & & & & & & & & \\
\hline
\end{tabular}

Catatan: ${ }^{* *} \mathrm{p}<0,01 ;{ }^{*} \mathrm{p}<0,05$; Jenis kelamin terdiri dari 1=laki-laki, 2=perempuan; Etnis terdiri dari; 1=Jawa, 2=Sunda, 3=Betawi, 4=Batak, 5=Minang, 6=Melayu, 7=Tionghoa, 8=Lainnya; Pengeluaran perbulan terdiri dari 1= kurang dari Rp 500.000; 2= Rp 500.000 - Rp 1 juta; 3= Rp 1 juta - Rp 2 juta; $4=$ Rp 2 juta - Rp 4 juta; $5=$ Rp 4 juta - Rp 7 juta, 6=lebih dari Rp 7 juta; Pendidikan terakhir terdiri dari 1=SD, 2=SMP, 3=SMA, 4=Diploma, 5=S1, 6=S2, 7=S3, 8=Lainnya.

Gambar 1.

Hasil Uji Model 1 Mediasi, RWA sebagai Prediktor

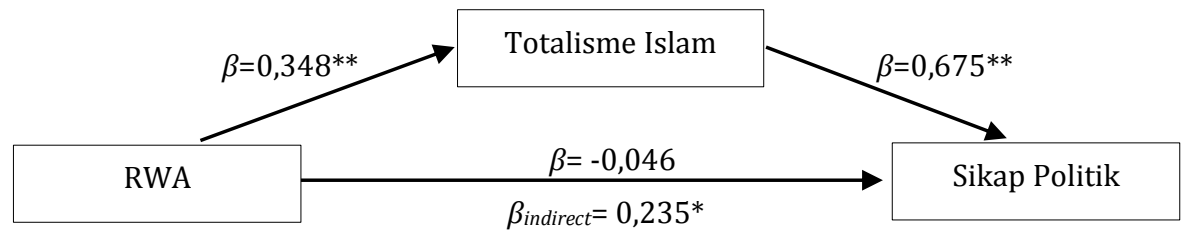

Catatan: ${ }^{* *} \mathrm{p}<0,01 ;^{*} \mathrm{p}<0,05$ 
Gambar 2.

Hasil Uji Model 2 Mediasi, SDO sebagai Prediktor

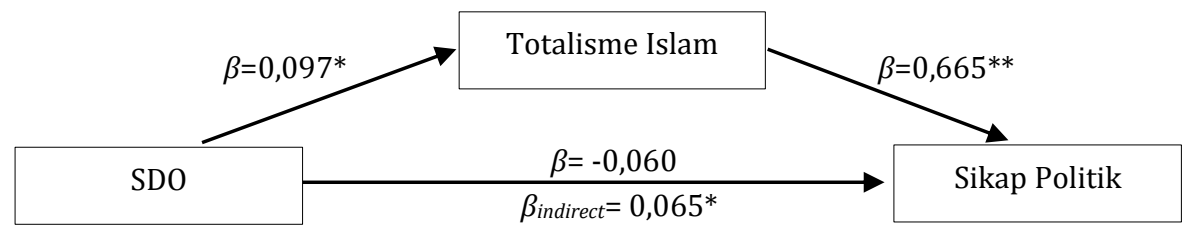

Catatan: ${ }^{* *} \mathrm{p}<0,01 ;{ }^{*} \mathrm{p}<0,05$

Tabel 2.

Hasil Uji Mediasi SDO dan RWA terhadap Sikap Politik melalui Totalisme Islam (Indirect Effect)

\begin{tabular}{lllll}
\hline Hubungan & $\begin{array}{l}\text { Coeff. } \\
(\boldsymbol{\beta})\end{array}$ & Boot S.E. & $\begin{array}{l}\text { CI 95\% } \\
\text { Lower }\end{array}$ & Upper \\
\hline RWA $\rightarrow$ Totalisme Islam $\rightarrow$ Sikap Politik & 0,235 & 0,032 & 0,167 & 0,293 \\
SDO $\rightarrow$ Totalisme Islam $\rightarrow$ Sikap Politik & 0,065 & 0,031 & 0,006 & 0,123 \\
\hline
\end{tabular}

Pada gambar 1, hasil analisis model 2 menemukan bahwa RWA tidak signifikan memprediksi sikap politik secara langsung (direct effect) tanpa melibatkan mediator (totalisme Islam $)(\beta=-0,046, t(525)=-1,310, p=0,187)$, hipotesis 2 ditolak.

Selanjutnya, kami menemukan RWA signifikan memprediksi totalisme Islam $(\beta=0,348$, $t(526)=8,516, p<0,01)$. Begitu pula totalisme Islam ditemukan signifikan memprediksi sikap politik $(\beta=0,675, t(525)=19,303, p<0,01)$, hipotesis 1 diterima. Pada hasil analisis efek mediator, kami menemukan bahwa totalisme Islam signifikan memediasi hubungan antara RWA dengan sikap politik $\left(\beta_{\text {indirect }}=0,235\right.$, Boot S.E. $=$ 0,032, CI 95\% [0,167, 0,293]), hipotesis 4 diterima (lihat tabel 2). RWA bersama-sama dengan totalisme mempunyai $43,6 \%$ varians yang memprediksi sikap politik $(F(2,525)=202,882, p<$ $\left.0,001, R^{2}=0,436\right)$.

Pada gambar 2, hasil analisis model 1 menemukan bahwa SDO tidak signifikan memprediksi sikap politik secara langsung (direct effect) tanpa melibatkan mediator (totalisme Islam) $(\beta=-0,060, t(525)=-1,837, p=0,0668)$, hipotesis 3 ditolak. SD0 ditemukan signifikan memprediksi totalisme Islam $(\beta=0,097, t(526)$ $=2,238, p<0,05)$. Totalisme Islam juga ditemukan signifikan memprediksi sikap politik $(\beta=$ $0,665, t(525)=20,214, p<0,01)$, hipotesis 1 diterima. Pada hasil analisis efek mediator, kami menemukan bahwa totalisme Islam signifikan memediasi hubungan antara SDO dengan sikap politik $\left(\beta_{\text {indirect }}=0,065\right.$, Boot S.E. $=0,031, C I 95 \%$ $[0,006,0,123])$, hipotesis 5 diterima (lihat tabel 2). SDO bersama-sama dengan totalisme mempunyai $43,8 \%$ varians yang memprediksi sikap politik $\left(F(2,525)=204,325, p<0,001, R^{2}=0,438\right)$.

\section{Diskusi}

Hasil kami mendukung hipotesis totalisme Islam memprediksi sikap politik konservatif (hipotesis 1 terkonfirmasi), sementara RWA dan SDO tidak dapat memprediksi secara langsung sikap politik konservatif (hipotesis 2 dan 3 tidak terkonfirmasi). Malka (2014) menjelaskan bahwa mengonseptualisasikan agama sebagai bagian dari "sindrom konservatif" yang luas dapat dibenarkan.

Studi ini telah menunjukkan korelasi positif antara RWA dengan sikap politik konservatif. Studi ini juga membuktikan adanya model hubungan RWA dengan sikap politik yang dimediasi oleh totalisme Islam. Hasil ini menunjukkan bahwa faktor agama menjadi variabel predisposisi dalam menentukan sikap politik seperti halnya variabel-variabel psikologi yang sudah banyak dibuktikan. Hubungan ini menunjukkan bahwa agama dan politik berakar pada kebutuhan psikologis yang sama (Friesen dkk., 2015), yaitu kebutuhan psikologis untuk mengelola ketidakpastian dan ancaman (Hennes, dkk., 2012). Sebagian Muslim memandang Islam bukan hanya semata-mata menyangkut ajaran tentang akidah (keyakinan) dan ibadah (penghambaan) melainkan juga pola perilaku dan muamalah (kemasyarakatan). Tidak ada satu aspek kehidupan yang lepas dari pengaturan Islam. Oleh karena itu Islam wajib diyakini, dipahami dan diamalkan dalam seluruh aspek kehidupan secara totalis atau kaffah (Nashir, 2013). Muslim yang seperti ini, kami menyebutnya sebagai "Muslim Totalis" umumnya mempunyai klaim bahwa umat Islam harus memiliki "Negara Islam," yaitu, negara yang mendasarkan semua hukum pada Syariah (Shepard, 1987), sesuai dengan sikap Muslim 
konservatif yang mendukung hukum Islam dan kekhalifahan, atau negara pan-Islam (Krance, 2003).

RWA berkorelasi signifikan dengan totalisme Islam, hal ini berkaitan dengan kepatuhan yang kuat pada nilai dan norma konvensional adalah salah satu dimensi sebagai sikap otoritarian (Altemeyer, 1988; Altemeyer \& Hunsberger, 1992). Tidak sesuai dengan hasil penelitian sebelumnya bahwa hubungan antara SDO dan religiusitas cenderung tidak signifikan (Altemeyer, 2004; Altemeyer \& Hunsberger, 1997; Heaven \& Connors, 2001) atau bahkan negatif, penelitian ini menemukan bahwa SDO berkorelasi positif dengan faktor agama yaitu totalisme Islam. Muslim dengan skor totalisme Islam tinggi dapat diartikan sebagai muslim yang mendukung Islam sebagai ideologi agama, menggunakan segala cara dalam pencarian tujuan yaitu penaklukan dunia. Hal ini sejalan dengan konsep SDO yaitu preferensi individu berdasarkan hierarki kelompok dan ketidaksetaraan.

RWA dan SDO digunakan Duckit dan Sibley (2010) serta Harnish dkk. (2018) untuk bisa memahami sikap konservatif. Melalui dual process motivation model, sikap politik sayap kanan (konservatif) terstruktur dari dua nilai sosial dasar yang berbeda atau dua motivasi yang berbeda. RWA dan SDO berakar dari perbedaan pandangan sosial, dimensi kepribadian, dan pengaruh lingkungan sosial. RWA memilih sikap politik konservatif yang menekankan hukum dan ketertiban dan mempertahankan nilai-nilai tradisional dan agama. Sedangkan SDO memilih partai-partai sayap kanan yang menekankan pada dukungan sosial berbasis kompetitif ketidaksetaraan, hierarki, dan dominasi kelompok.

Hipotesis modernasi diferensial menunjukkan RWA dan SDO dipengaruhi perbedaan proses sosial yang mempengaruhi prasangka dan politik, individu dengan RWA yang tinggi akan sangat reaktif terhadap ancaman keamanan kolektif (misal, terhadap tatanan sosial, stabilitas, tradisi, dan kohesi), akan mendukung pihak atau kebijakan yang mengendalikan atau mengelola ancaman. RWA (tindakan serupa sikap atau nilai-nilai otoriter) lebih kuat memprediksi permusuhan outgroup atau partai sayap kanan atau dukungan kebijakan di bawah kondisi yang mengancam sosial (misalnya, Cohrs \& Ibler, 2009). Sementara individu dengan SDO yang tinggi akan sangat sensitif terhadap hubungan dominasi antar kelompok, ketidaksetaraan, dan kebijakan yang bertujuan untuk mempertahankan atau membangun dominasi dan ketidaksetaraan kelompok. SDO akan lebih memprediksi prasangka, agresi, kecurangan, pada situasi yang harus meningkatkan daya saing, dominasi atau superioritas (Bilewicz,
Soral, Marchlewska, \& Winiewski, 2017; Cozzolino \& Snyder, 2008; Eibach \& Keegan, 2006; Passini \& Morselli, 2016; Perry, Sibley, \& Duckitt, 2013).

Pada penelitian ini sikap politik konservatif juga dapat dijelaskan dengan struktur RWA dengan mediasi totalisme Islam. RWA mempunyai ciri kepercayaan pada kontrol sosial, kepatuhan, penghormatan otoritas, menyesuaikan dengan norma moral, tradisional dan agama yang berkorelasi dengan religiusitas dan pandangan tentang dunia sosial yang mengancam dan berbahaya (Duckitt \& Sibley, 2009; 2010). Modernisasi dan sekularisasi merupakan karakteristik krisis yang mengancam dan berbahaya untuk dihadapi dunia Muslim (Dekmejian, 1988). Modernisasi melahirkan sekularisasi yang mengakibatkan sentimen dan praktik agama menurun ketika masyarakat mencapai tahap pembangunan yang lebih tinggi. Ini mungkin karena kemajuan ilmiah dan teknologi membuat kepercayaan agama tampak tidak masuk akal, lembaga dan organisasi yang mendukung tatanan sosial dan mengatur agama kurang diperlukan (Malka, 2014). Akibatnya modernitas dianggap sebagai ancaman bagi kemurnian ajaran. Modernitas sebagai dunia sosial yang secara inheren berbahaya, tidak dapat diprediksi, dan mengancam (bukan tempat yang aman, stabil, dan aman). Muslim dengan RWA yang tinggi akan mendukung pihak atau kebijakan yang mengendalikan atau mengelola ancaman. Mereka yang mendukung totalisme Islam berarti meyakini bahwa ajaran Islam bukan hanya sebagai agama yang dapat memberikan pedoman dalam mengendalikan atau mengelola ancaman. Muslim akan menggunakan agama sebagai pertimbangan utama dalam pembuatan kebijakan karena agama Islam sebagai ajaran sempurna diyakini dapat memberikan panduan hidup total dalam menghadapi modernisasi atau sekularisasi yang dianggap sebagai krisis yang mengancam (Dekmejian, 1988).

Sementara pada mediasi totalisme Islam pada SDO dan sikap politik, SDO mempunyai ciri menentang kesetaraan, dominasi kelompok dan berkorelasi dengan prestasi, hedonisme, dan pandangan dunia sebagai kompetisi antara yang kuat dan lemah. Pandangan dunia yang kompetitif ini membuat nilai atau tujuan motivasi dari kekuasaan, dominasi, dan superioritas melebihi yang lain (Duckitt \& Sibley, 2009; 2010). Dalam penelitian ini, salah satu item sikap politik yang diukur adalah tentang pemimpin non-muslim. Muslim dengan SDO tinggi memandang dunia sosial sebagai persaingan antara ingroup-outgroup. Muslim tidak akan mendukung nonMuslim (outgroup) menjadi pemimpin secara langsung melainkan dimediasi oleh keyakinan 
Muslim bahwa sebuah negara berdasarkan Syariah Islam yang tentunya tidak seharusnya dipimpin oleh non muslim.

Modernisasi dan sekularisasi dianggap sebagai krisis yang mengancam integritas kebudayaan dan way of life Islam. Kondisi tersebut terjadi karena tidak berhukum pada syariat Islam yang bersumber dari Allah. Menurut beberapa muslim jalan Islam-lah yang mengeluarkan dan menjadi solusi dalam mengatasi krisis tersebut. Jalan Islam itu adalah dengan menyakini bahwa ajaran Islam yang lengkap dan sempurna, mempertautkan secara integratif kehidupan dunia termasuk kehidupan politik (siyasat, daulat, dan hukum Syariah) yang dikenal dengan kesatuan al-diin wa daulat wa syariat (Nashir, 2013). Islam dianggap tidak hanya sebagai "agama" dalam arti sempit dari kepercayaan teologis, doa pribadi, dan ibadah ritual, tetapi juga sebagai cara hidup secara menyeluruh dengan panduan untuk perilaku politik (totalis).

\section{Kesimpulan}

Temuan dan penjelasan penting pada hasil riset ini adalah, pertama, RWA dan SDO lemah memprediksi sikap politik konservatif pada Muslim Indonesia. Pada analisis korelasional, RWA memang cukup signifikan berkorelasi dengan sikap politik, tetapi tidak dengan SDO. Kedua, faktor yang penting menjelaskan peran RWA dan SDO pada sikap politik konservatif Muslim Indonesia adalah faktor religiusitas, yakni totalisme Islam. Kami menemukan totalisme Islam memediasi secara penuh peran RWA dan SDO terhadap sikap politik konservatif. Dua hal yang menjadi dasar penjelasan pola efek mediasi totalisme Islam ini adalah (1) adanya modernisasi memunculkan ancaman dan ini erat kaitannya dengan totalisme Islam; (2) adanya kekuasaan dan ketakutan atas dominasi kelompok minoritas (nonMuslim) sebagai penguasa. Maka kami menggunakan istilah "Muslim Totalis" untuk menggambarkan kondisi sikap politik Muslim pada temuan kami, yaitu Muslim yang berusaha secara totalitas untuk penegakan hukum berbasis agama Islam.

Penelitian ini memiliki keterbatasan yang perlu diperhatikan sebagai rujukan bagi peneliti yang ingin melanjutkan topik penelitian serupa. Batasan pertama adalah pada sampel penelitian yang hanya mengumpulkan data pada mahasiswa Muslim. Usaha generalisasi dibutuhkan untuk menjelaskan temuan ini pada masyarakat Muslim luas di Indonesia. Batasan berikutnya adalah riset dilakukan dengan desain korelasional, perlu untuk mengembangkan riset selanjutnya dengan menggunakan kaidah kausalitas, yaitu melalui eksperimental.

\section{Daftar Pustaka}

Altemeyer, B. (1981). Right-wing authoritarianism. Winnipeg, Manitoba, Canada: University of Manitoba Press.

Altemeyer, B. (1988). Enemies of freedom: Understanding right-wing authoritarianism. San Francisco, CA: Jossey-Bass.

Altemeyer, B. (1996). The authoritarian specter. Cambridge, MA: Harvard University Press.

Altemeyer, B. (1998). The other "authoritarian personality." In M. P. Zanna (Ed.), Advances in experimental social psychology (Vol. 30, pp. 47-92). Academic Press. https://doi.org/10.4324/978020350598 4-4

Altemeyer, B. (2004). Highly dominating, highly authoritarian personalities. Journal of Social Psychology, 144, 421-447. https://doi.org/10.3200/SOCP.144.4.421 $-448$

Altemeyer, B., \& Hunsberger, B. E. (1992). Authoritarianism, religious fundamentalism, quest, and prejudice. International Journal for the Psychology of Religion, 2, 113-133. https://doi.org/10.1207/s15327582ijpr0 202_5

Altemeyer, B., \& Hunsberger, B. E. (1997). Amazing conversions: Why some turn to faith\&others abandon religion. Amherst, MA: Prometheus.

Antonenko Young, O., Willer, R., \& Keltner, D. (2013). "Thou shalt not kill": Religious fundamentalism, conservatism, and rulebased moral processing. Psychology of Religion and Spirituality, 5(2), 110-115. https://doi.org/10.1037/a0032262

Azra, A. (2003). Demokrasi, hak asasi manusia, masyarakat madani. Jakarta. Prenada Media

Badan Pusat Statistik. (2010). Kewarganegaraan, suku bangsa, agama, dan bahasa sehari-hari penduduk Indonesia, hasil sensus penduduk 2010. Badan Pusat Statistik. https://www.bps.go.id/publication/2012 /05/23/55eca38b7fe0830834605b35/ke warganegaraan-suku-bangsa-agama-danbahasa-sehari-hari-pendudukindonesia.html

Banyasz, A. M., Tokar, D. M., \& Kaut, K. P. (2016). Predicting religious ethnocentrism: Evidence for a partial mediation model. Psychology of Religion 
and Spirituality, 8(1), 25-34. https://doi.org/10.1037/rel0000020

Bilewicz, M., Soral, W., Marchlewska, M., \& Winiewski, M. (2017). When authoritarians confront prejudice. Differential effects of SDO and RWA on support for hate-speech prohibition. Political Psychology, 38(1), 87-99. https://doi.org/10.1111/pops.12313

Bruinessen, M.V. (2013). Contemporary developments in Indonesian Islam explaining the 'Conservative Turn'. ISEAS. Singapore

Cohrs, J. C., \& Ibler, S. (2009). Authoritarianism, threat, and prejudice: An analysis of mediation and moderation. Basic and Applied Social Psychology, 31(1), 81-94. https://doi.org/10.1080/019735308026 59638

Cohrs, J. C., Kielmann, S., Maes, J., \& Moschner, B. (2005). Effects of right-wing authoritarianism and threat from terrorism on restriction of civil liberties. Analyses of Social Issues and Public Policy, 5, 263-276. https://doi.org/10.1111/j.15302415.2005.00071.x

Cozzolino, P. J., \& Snyder, M. (2008). Good times, bad times: How personal disadvantage moderates the relationship between social dominance and efforts to win. Personality and Social Psychology Bulletin, 34(10), 1420-1433. https://doi.org/10.1177/014616720832 1595

Dekmejian, R. H. (1988). Islamic revival: Catalysts, categories, and consequences. In S. T. Hunter (Ed), The Politics of Islamic Revivalism: Diversity and Unity (pp. 3-19). Bloomington and Indianapolis: Indiana University Press.

De Grada, E., Kruglanski, A. W., Mannetti, L., \& Pierro, A. (1999). Motivated cognition and group interaction: Need for closure affects the contents and processes of collective negotiations. Journal of Experimental Social Psychology, 35(4), 346-365. http://doi.org/10.1006/jesp.1999.1376

Dru, V. (2007). Authoritarianism, social dominance orientation and prejudice: Effects of various self-categorization conditions. Journal of Experimental Social Psychology, 43(6), 877-883. https://doi.org/10.1016/j.jesp.2006.10.0 08

Duckitt, J., \& Sibley, C. G. (2009). A dual-process motivational model of ideology, politics, and prejudice. Psychological Inquiry, 20(2-
3),

98-109. https://doi.org/10.1080/104784009030 28540

Duckitt, J., \& Sibley, C. G. (2010). Personality, ideology, prejudice, and politics: A dualprocess motivational model. Journal of personality, 78(6), 1861-1894. https://doi.org/10.1111/j.14676494.2010.00672.x

Duckitt, J., Bizumic, B., Krauss, S. W., \& Heled, E. (2010). A tripartite approach to rightwing authoritarianism: The authoritarianism-conservatismtraditionalism model. Political Psychology, 31(5), 685-715. https://doi.org/10.1111/j.14679221.2010.00781.x

Dupree, C. H., \& Fiske, S. T. (2019). Selfpresentation in interracial settings: The competence downshift by White liberals. Journal of Personality and Social Psychology, 117(3), 579-604. https://doi.org/10.1037/pspi0000166

Effendy, B. (1998). Islam dan Negara : Transformasi Pemikiran dan Praktik Politik Islam di Indonesia. Jakarta. Paramadina

Eibach, R. P., \& Keegan, T. (2006). Free at last? Social dominance, loss aversion, and white and black Americans' differing assessments of racial progress. Journal of Personality and Social Psychology, 90(3), 453-467. https://doi.org/10.1037/00223514.90.3.453

Fealy, G., \& White, S. (Eds.). (2008). Expressing Islam: Religious life and politics in Indonesia. Institute of Southeast Asian Studies.

Friesen, J. P., Campbell, T. H., \& Kay, A. C. (2015). The psychological advantage of unfalsifiability: The appeal of untestable religious and political ideologies. Journal of personality and social psychology, 108(3),

515. https://doi.org/10.1037/pspp0000018

Hannover, B., Gubernath, J., Schultze, M., \& Zander, L. (2018). Religiosity, religious fundamentalism, and ambivalent sexism toward girls and women among adolescents and young adults living in Germany. Frontiers in Psychology, 9, 2399, 1-17. https://doi.org/10.3389/fpsyg.2018.023 99

Harnish, R. J., Bridges, K. R., \& Gump, J. T. (2018). Predicting economic, social, and foreign policy conservatism: The role of rightwing authoritarianism, social dominance orientation, moral foundations 
orientation, and religious fundamentalism. Current Psychology: A Journal for Diverse Perspectives on Diverse Psychological Issues, 37(3), 668-679. https://doi.org/10.1007/s12144-0169552-x

Haslam, N., \& Levy, S. R. (2006). Essentialist beliefs about homosexuality: Structure and implications for prejudice. Personality and Social Psychology Bulletin, 32(4), 471-485. https://doi.org/10.1177/014616720527 6516

Hassan, R. (2015). Muslim identity formation and social-political involvement. In D. Iner, \& S. Yucel (eds), Muslim Identity Formation in Religiously Diverse Society (pp. 19-35). Cambridge Scholars Publishing

Hathcoat, J. D., \& Barnes, L. L. B. (2010). Explaining the relationship among fundamentalism and authoritarianism: An epistemic connection. International Journal for the Psychology of Religion, 20(2), 73-84. https://doi.org/10.1080/105086110036 07884

Hayes, A. F. (2018). Introduction to mediation, moderation, and conditional process analysis: A regression-based approarch. New York. Guilford Press.

Heaven, P. C., \& Connors, J. R. (2001). A note on the value correlates of social dominance orientation and right-wing authoritarianism. Personality and Individual Differences, 31(6), 925-930. https://doi.org/10.1016/S01918869(00)00194-X

Hennes, E. P., Nam, H. H., Stern, C., \& Jost, J. T. (2012). Not all ideologies are created equal: Epistemic, existential, and relational needs predict system-justifying attitudes. Social Cognition, 30(6), 669688. https:// doi/10.1521/soco.2012.30.6.669

Ho, A. K., Sidanius, J., Pratto, F., Levin, S., Thomsen, L., \& Kteily, N. (2012). Social dominance orientation: Revisiting the structure and function of a variable predicting social and political attitudes. Personality and Social Psychology Bulletin, 38(5), 583-606. https://doi.org/10.1177/014616721143 2765

Izomiddin, I. (2017). Menggugat Kebhinekaan: Respon Intelektual Muda Program Pascasarjana UIN Raden Fatah Palembang terhadap Kepemimpinan Non Muslim. Intizar, 23(2), 215-240. https://doi.org/10.19109/intizar.v23i2.2 182

Johnson, M. K., Rowatt, W. C., Barnard-Brak, L. M., Patock-Peckham, J. A., LaBouff, J. P., \& Carlisle, R. D. (2011). A mediational analysis of the role of right-wing authoritarianism and religious fundamentalism in the religiosityprejudice link. Personality and Individual Differences, 50(6), 851-856. https://doi.org/10.1016/j.paid.2011.01.0 10

Johnson, M. K., Labouff, J. P., Rowatt, W. C., Patock-Peckham, J. A., \& Carlisle, R. D. (2012). Facets of right-wing authoritarianism mediate the relationship between religious fundamentalism and attitudes toward Arabs and African Americans. Journal for the Scientific Study of Religion, 51(1), 128-142. https://doi.org/10.1111/j.14685906.2011.01622.x

Jost, J. T. (2007). Coda: After "The end of the end of ideology"-Reply to Glassman and Karno (2007) and Unger (2007). American Psychologist, 62, 1077-1080. https://doi.org/10.1037/0003066X.62.9.1077

Jost, J. T., Glaser, J., Kruglanski, A. W., \& Sulloway, E J. (2003). Political conservatism as motivated social cognition. Psychological Bulletin, 129(3), 339-375. https://doi.org/10.1037/00332909.129.3.339

Jost, J. T., Nosek, B. A., \& Gosling, S. D. (2008). Ideology: Its resurgence in social, personality, and political psychology. Perspectives on Psychological Science, 3(2), 126-136. https://doi.org/10.1111/j.17456916.2008.00070.x

Kelly, N. J., \& Morgan, J. (2008). Religious traditionalism and Latino politics in the United States. American Politics Research, 36(2), 236-263. https://doi.org/10.1177/1532673X0730 9738

Kraince, R. G. (2003). The Role of Islamic Student Activists in Divergent Movements for Reform during Indonesia's Transition from Authoritarian Rule, 1998-2001 (Doctoral Dissertation). Ohio University, United States.

Kraince, R. G. (2000). The role of Islamic student groups in the reformasi struggle: KAMMI (Kesatuan Aksi Mahasiswa Muslim Indonesia). Studia Islamika, 7(1). 1-50. https://doi.org/10.15408/sdi.v7i1.715 
Layman, G. C., \& Green, J. C. (2005). Wars and rumours of wars: The contexts of cultural conflict in American political behavior. British Journal of Political Science, 36(1), 61-89.

https://doi.org/10.1017/S00071234060 00044

Lazar, A., \& Hammer, J. H. (2018). Religiousness and anti-gay/lesbian attitudes: The mediating function of intratextual religious fundamentalism. Psychology of Violence, $\quad 8(6)$, 763-771. https://doi.org/10.1037/vio0000197

Lifton, M.D.(1989). Thought Reform and the Psychology of Totalism : A Study of Brainwashing in China The University of North Carolina Press

Lindsey, T. (2016,). Blasphemy charge reveals real fault lines in Indonesian Democracy. Indonesia at Melbourne.

Lockwood, C. M., \& MacKinnon, D. P. (1998, March). Bootstrapping the standard error of the mediated effect. In Proceedings of the 23rd annual meeting of SAS Users Group International (pp. 997-1002)

Malka, A., Soto, C. J., Inzlicht, M., \& Lelkes, Y. (2014). Do needs for security and certainty predict cultural and economic conservatism? A cross-national analysis. Journal of Personality and Social Psychology, 106(6), 1031-1051. https://doi.org. 10.1037/a0036170

Malka, A., Lelkes, Y., Srivastava, S., Cohen, A. B., \& Miller, D. T. (2012). The association of religiosity and political conservatism: The role of political engagement. Political Psychology, 33(2), 275-299. https://doi.org/10.1111/j.14679221.2012.00875.x

Mietzner, M., \& Muhtadi, B. (2018). Explaining the 2016 Islamist mobilisation in Indonesia: Religious intolerance, militant groups and the politics of accommodation. Asian Studies Review, 42(3), 479-497. https://doi.org/10.1080/10357823.2018 .1473335

Mifune, N. \& Yokota, K. (2018). The external validity of the relationship between social dominance orientation and political or discriminatory attitudes toward foreigners using a Japanese sample. The Japanese Journal of Social Psychology, 34(2), 94-101.

Mujani, S. (2007). Muslim Demokrat. Islam, Budaya Demokrasi dan Partisipasi Politik di Indonesia Pasca Orde Baru. Jakarta, Gramedia Pustaka Utama
Muluk, H., Hudiyana, J., \& Shadiqi, M. A. (2018). The development of psychology of culture in Indonesia. In W. W. Li, D. Hodgetts, \& K. H. Foo (Eds.), Asia-Pacific perspectives on intercultural psychology (pp. 140-156). Routledge. https://doi.org/10.4324/978131515835 8-8.

Muluk, H., Milla, M. N., Yustisia, W., Arifin, H. H., Hudiyana, J., Assegaf, S. A. H., Istiqomah, I., \& Shadiqi, M. A. (2018). Properti Psikometri Alat Ukur Ideologi Politik Indonesia (Working Paper).

Nashir, H. (2013). Islam Syariat Reproduksi Salafiyah Ideologis di Indonesia. Bandung. Mizan Pustaka

Ng, M., \& Lin, J. (2016).Testing for mediation effects under non-normality and heteroscedasticity: A comparison of classic and modern methods. International Journal of Quantitative Research in Education, 3(1-2), 24-40. https://doi.org/10.1504/ijqre.2016.0736 43

Passini, S. (2017). Different ways of being authoritarian: The distinct effects of authoritarian dimensions on values and prejudice. Political Psychology, 38(1), 7386. https://doi.org/10.1111/pops.12309

Passini, S., \& Morselli, D. (2016). Blatant domination and subtle exclusion: The mediation of moral inclusion on the relationship between social dominance orientation and prejudice. Personality and Individual Differences, 89, 182-186. https://doi.org/10.1016/j.paid.2015.10.0 22

Perry, R., Sibley, C. G., \& Duckitt, J. (2013). Dangerous and competitive worldviews: A meta analysis of their associations with social dominance orientation and rightwing authoritarianism. Journal of Research in Personality, 47(1), 116-127. https://doi.org/10.1016/j.jrp.2012.10.00 4

Tsang, J.-A., \& Rowatt, W. C. (2007). The relationship between religious orientation, right-wing authoritarianism, and implicit sexual prejudice. The International Journal for the Psychology of Religion, 17(2), 99-120. https://doi.org/10.1080/105086107012 44122

Theodorou, A. E. (2015, December 25). Americans are in the middle of the pack globally when it comes to importance of religion. Pew Research Center. Retrieved from https://www.pewresearch.org/facttank/2015/12/23/americans-are-in-the- 
middle-of-the-pack-globally-when-itcomes-to-importance-of-religion/

Pratto, F., Sidanius, J., Stallworth, L. M., \& Malle, B. F. (1994). Social dominance orientation: A personality variable predicting social and political attitudes. Journal of personality and social psychology, 67(4), 741. https://doi.org/10.1037/00223514.67.4.741

Roccato, M. (2008). Right-wing authoritarianism, social dominance orientation, and attachment: An Italian study. Swiss Journal of Psychology/Schweizerische Zeitschrift für Psychologie/Revue Suisse de Psychologie, 67(4),

219. https://doi.org/10.1024/14210185.67.4.219

Sakai, M., \& Fauzia, A. (2014). Islamic orientations in contemporary Indonesia: Islamism on the rise?. Asian Ethnicity, 15(1), 41-61. https://doi.org/10.1080/14631369.2013 .784513

Shepard, W. E. (1987). Islam and ideology: Towards a typology. International Journal of Middle East Studies, 19(3), 307-336. https://doi.org/10.1017/S00207438000 56750

Sinn, J. S., \& Hayes, M. W. (2018). Is political conservatism adaptive? Reinterpreting right wing authoritarianism and social dominance orientation as evolved, sociofunctional strategies. Political Psychology. Advance online publication. https://doi.org/10.1111/pops.12475

Stangor, C. (2011). Research methods for the behavioral sciences. Wadsworth, Cengage Learning.

Webster, D. M., \& Kruglanski, A. W. (1994). Individual differences in need for cognitive closure. Journal of Personality and Social Psychology, 67(6), 1049-1062. https://doi.org/10.1037/00223514.67.6.1049

Wilson, M. S., \& Sibley, C. G. (2012). Social Dominance Orientation and Right-Wing Authoritarianism: Additive and Interactive Effects on Political Conservatism. Political Psychology, 34(2), 277-284. doi:10.1111/j.1467- 